\title{
The Stage of Corporate Social Responsibility in EU- CEE Countries
}

\author{
Irene Guia Arraiano ${ }^{1}$ and Camelia Daniela Hategan ${ }^{2}$
}

\begin{abstract}
In the European Union, the importance of Corporate Social Responsibility reporting is increasing, because 2017 is the year in which the CSR reporting of large companies passes from the voluntary to the mandatory stage according to the requirements of the European Directive 2014/95/EU. In this context, this paper aims to examine the stage of Corporate Social Responsibility in Central and Eastern European Countries members of European Union, in accordance with Global Reporting Initiative which is consistent with globally recognised criteria worldwide, in the period 2002-2018. A critical analysis of the quality of the reporting was performed, looking at whether it has improved over the previous year and whether it respects legal requirements, and whether the communicated information is useful to the stakeholders. Base on literature review it was found that there is a gap of Corporate Social Responsibility's reporting research to Western European countries. The results show that the evolution of reporting practices has improved over the years for the all countries and the most reports are prepared by multinationals companies. Thus, we can see how companies react to regulatory requirements and other government demands.
\end{abstract}

Keywords: Corporate Social Responsibility, reporting, Global Reporting Initiative, Central and Eastern European Countries, quality

\section{Introduction}

In European Union (EU) the importance of Corporate Social Responsibility (CSR) reporting is increasing, because 2017 is the year in which the CSR reporting of large companies passes from the voluntary to the mandatory stage according to the requirements of the European Directive 2014/95/EU. In order to increase the investor's confidence and the competitiveness of companies, it is necessary to increase the transparency of the information published by them in order to develop in the long run and to improve their reputation.

The literature suggests that there is a gap in economic development between the Western and Eastern EU countries, which is also a gap in CSR activities (Steurer and Konrad, 2009). Therefore, the role of the Directive is to establish a common framework for all the countries and contribute to a better reporting of information that can be relevant for stakeholders to reduce the gap between countries in the field of CSR (Horvath et al., 2017.a).

In this context the paper aims to examine the stage of CSR in Central and Eastern European Countries members of European Union (EU-CEE), in accordance with Global Reporting Initiative (GRI) which is consistent with globally recognized criteria worldwide, in the period 2002-2018. In the paper is made an analysis of the implementation of the Directive 2014/95/EU in the 11 countries and a critical analysis of the quality of the reporting base on GRI reports of companies from these countries. 
The paper contributes to literature with an updated analysis of topical CSR and showing that there is an evolution of reporting practices has improved over the years for the EUCEE countries, the most GRI reports are prepared by multinationals companies and the implementation of European Directive 2014/95/EU has led to a decrease in the number of reports.

The remainder of the article is organized as follows. The literature review and theoretical framework are described in section 2. The section 3 presents the methodology and database used in this research. The results of the qualitative analysis are described in section 4 and section 5 contain the conclusions.

\section{Literature Review and Theoretical Framework}

\subsection{Literature Review}

The CSR literature includes many qualitative and quantitative research that studied the impact of CSR on performance and reputation of companies, also the regulation of CSR activities and reporting them, the transparency of information provided to stakeholders. CSR has become a global phenomenon, so there are many international and national studies. Thus, researchers from EU countries have conducted individual studies for each country, but also comparative research between different EUCEE countries, or between East and Western EU countries.

A research consortium from EU-CEE countries conducted a study to establish the state of CSR reporting in EU-CEE countries and how was managed, based on a questionnaire applied in 50 largest companies from which it resulted there are differences in reporting, the tasks of the managers regarding sustainability and the scale of the formalization process (Horvath et al, 2017.b).

Steurer et al (2012) conducted a research which showed that the governments in the Western European countries are promoting CSR more intense than East governments and found that public policies reinforce CSR.

For the literature review valuable research published in last five years in journals with high visibility has been considered, where studies have been identified for each country, written by the authors from the all EU-CEE countries, whose synthesis is presented below, in alphabetical order of countries name.

Simeonov and Stefanova (2015) studied the general context of CSR in Bulgaria and found that the most Bulgarian companies did not have much knowledge about CSR. The future development of CSR depends on the ability of the public policies to develop and implement an updated CSR strategy, also on the ability of the companies, the institutions and civil society to collaborate at strategic level.

The studies carried out in the Czech Republic have referred to the factors that influence CSR and the sustainability reporting. Skýpalová et al (2016) studied the correlation between company size, awareness, commitment and number of CSR activities based on answers from questionnaire on sample of 1013 small and mediumsized enterprises (SMEs) in period 2013-2014 and founded that the involvement of organizations in CSR activities increases with the size of the organization. On the other hand, Petera et al (2016) conducted a study on perception and interpretation of sustainability among the 13 largest corporations established in the Czech Republic from 
"Czech top 100" bases on semi-structured interviews made in April 2015. Most respondents perceived the sustainability with its components: economic, environmental and social, and the sustainability initiatives are both internal and external. Sustainability reporting was a relatively new topic for respondents, but its importance is increasing, according with GRI guidelines.

The researchers from Croatia studied the perception regarding CSR and the quality of sustainability reports. Peršić and Halmi (2018) conducted a research on the quality of sustainability reports of 38 Croatian companies with 400-500 employees for the year 2014. Based on the assessment of information according to GRI G4 requirements, Croatian companies have shown certain social information, whose reliability may be questionable in the comparative assessment since at that time the minimum information to be submitted was not established.

In the case of Estonia less relevant research has been published, can be remarked the study made by Kooskora (2015), regarding the activity of CSR awareness based on the Responsible Business Index in Estonia in 2009-2012 and concluded that leaders have begun to move closer to ethics and accountability within their organizations and to respect these principles as part of their activities.

In Hungary was made analysis regarding CSR activities and CSR communication. Borbély et al (2014) collected information on CSR activities from the top 100 companies in Hungary and found that $70 \%$ of the companies surveyed provided information on the website, most of which were environmental protection, education and health, and the companies most polluting ones have carried out the most activities. Pataki et al (2015) analyzed the CSR online communication of the top Hungarian companies and found that there was no positive correlation between unethical activities and the intensity of online CSR communication. In some highly controversial areas, companies are intensely communicating their actions on CSR and committing various forms of offense on the other.

In the case of Latvia, as in the case of Estonia, there is less research, but a relevant study may be considered the one written by Tambovceva et al (2017) regarding the perception of CSR and sustainability in middle-sized and large companies from Latvia base on survey conducted in 2015 on a sample of 59 companies. The representatives of companies are aware of the positive role of CSR whose importance will increase in the future, but investments in these activities do not increase at the same rate.

Lithuania is the country in the Baltic region where researchers have published several studies on CSR. Dagiliene et al (2014) analyzes a transparency of CSR reporting of the companies included in National Responsible Business Network Lithuania in period 2008-2011. The findings of the research consisted in improving the reporting process of CSR by strengthening the legal framework and improving the legal conditions for voluntary reporting, but the regulatory mechanism is not enough, because trust is always linked to the main values that companies and managers manage. Also Leitoniene and Sapkauskiene (2015) examine the quality of the CSR reporting of 48 companies from Lithuania for year 2013. The research has shown that the number of companies reporting voluntarily is increasing and the quality of reports is higher for listed companies and for sectors with significant environmental impacts.

The authors from Poland have published many quantitative and qualitative research that 
focused on quality of CSR reporting for listed companies on the Warsaw Stock Exchange (WSE). Matuszak and Rózanska (2017) analyze whether listed companies compile non-financial reports in line with the new requirements of the Directive. Based on data from a sample of 150 listed companies at WSE for year 2015, in most cases corporate disclosure of CSR was not in line with new requirements, suggesting that the new reporting obligation should increase the magnitude and quality of non-financial disclosure. Maj (2018) also studied reports for year 2016 of 430 Polish companies listed on the WSE, if these were prepared according to the GRI-G4 guidelines. The conclusion was that only 34 companies have disclosed non-financial information, and their publication also depends on the sector of activity. Most of the information published was about environmental protection mechanisms.

In Romania, as in Poland, many theoretical and empirical research on CSR has been carried out. Ogrean (2017) performs a strategic diagnostic analysis on the CSR practices and CSR reporting in Romania, based on the implementation of the Directive 2014/95/EU, in order to establish a prediction of its consequences and impacts. Dura and Driga (2017) analyzed the sustainability reports of the multinational companies present in Romania, and in particular the sustainability report of OMV Petrom for year 2011, the largest company in Romania, and found it to be considered as an example of good practice CSR and reporting. Also, empirical studies aimed at analyzing the relationship between CSR and Romanian companies' performance, and the results were different depending on the variables considered, but in most cases a positive relationship was identified (Simionescu and Dumitrescu, 2018).

In Slovakia, studies have been conducted on CSR reporting practices and their links with business performance. Pakšiová (2016) assessed the sustainability reports prepared for 2013 by the top 50 companies (depending on sales volume) in some industrial sectors in Slovakia and the results showed that $28 \%$ of the companies published a report and $56 \%$ of companies have published this information as part of their annual reports, also the prepared reports were not standardized. Rajnoha et al (2016) analyzed the different steps in measuring and managing business performance as well as measuring the impact of selected performance measurement instruments on the overall performance of Slovak enterprise enterprises and highlighting the ratio between the composite index of sustainable development with business performance. The results showed the very important link between the business strategy and the corporate performance measurement and management system, which is positively reflected in the achievement of global performance.

Slovenia is a country that borders with Western European countries and this neighborhood can have a positive influence on the economy. Golob and Podnar (2014) started from these premises in their research but found that the CSR practices are slightly different in Slovenia, even if there is a strong trade union movement that should be involved in increasing the working conditions of employees and implicitly in social activities, so unions should be more visible in relation to CSR. Kukanja et al (2016) investigated social responsibility practices in the restaurants industry, significant economic area in Slovenia, and the factors that influence them. In study managers' demographics were taken into account and the results were based on responses to direct interviews with 200 restaurant managers in the early part of 2015. The final conclusion 
was that the main reason for acting responsibly is related to the age, experience and level of education of managers.

The studies presented above show that the most important concerns of the researchers were the awareness of CSR, the types of CSR activities carried out by companies and the transparency of the information in the sustainability reports. The overall conclusion was that there is still much to be done, but the trend is rising and the companies have understood that CSR can only bring them benefits. The quality of the reports published in the last years is rising and more and more companies have reported according to GRI standards.

Most studies have been published by researchers in Poland and Romania, these being the countries with the largest population from EU-CEE countries. Comparative research has also been carried out between these two countries, showing that Poland has a higher level of CSR activities and transparency of information, especially for listed companies (Dumitru et al, 2016). CSR practices have also been compared between two countries, such as the study by Strouhal et al. (2015) which analyzed the relationship between implementation of CSR reporting and the performance of companies from Estonia and the Czech Republic and found that there is no direct link between these variables in both countries.

Comparative studies have also been carried out on groups of countries. Habek (2017) assessed the CSR reporting practices of the companies in the Visegrad Group countries (Czech Republic, Hungary, Poland and Slovakia) and found them need to be improved, the highest indicator of CSR reporting was achieved by Hungary, and the lower, by Slovakia.

\subsection{Regulatory framework and Global Reporting Initiative}

The European Commission issued several directives since 2001 and intended to make Europe a milestone in terms of social responsibility. In this sense, we must highlight the publication of the COM 2001366 (Green Paper) in , 2001, and the COM 2002347 in 2002, where a strategy for CSR was presented, inviting companies in a voluntary basis adopt social, environmental, and economic goals in their relations with the stakeholders, with the aim of directing investors to companies that publish sustainability reports.

As CEE countries became part of the European Union (EU), they felt the pressure to become CSR, although on a voluntary basis, and comply with European Commission directives. The European Union introduced a new directive on non-financial reporting, which should be implemented into member state legislation in 2016 and effective in business year 2017. European Parliament adopted the EU directive 2014/95/EU on 22 October 2014 when the Official Journal of the European Union (the official compendium of EU legislation) published the announcement of the directive. In addition to the directives issued by the European Commission, governments have created their own legislation by encouraging companies to submit a social responsibility report and implement sustainability strategies in management.

However, cultural and moral values differences exist between different CEE countries that occupy a wide geographical spread, which are reflected in the strategy that is followed by the companies in terms of social responsibility and sustainability. One of the 
main cultural differences comes from language and religion, how ethics and culture interact. The nationality of a company matters to its CSR practices and strategies of sustainability in management. Scholtens \& Dam (2007) have shown that there are significant differences between countries in social responsibility policies. The authors analyse ethical policies of firms in 24 industrialized countries and concluded that individualism and avoidance are positively associated with a firm's ethical policies, whereas masculinity and power distance are negatively related to these kinds of policies. Gjolberg (2009) also demonstrate significant cross-national differences between in how companies approach CSR and sustainability.

Sustainability reports enable organizations to understand and manage its impacts in a wide range of sustainability issues, allowing these to be more transparent about the risks and opportunities they face and make strategic decisions smarter. This is the purpose of private companies that analyze and classify sustainability reports, taking into account the three main aspects of sustainability, environmental, social and economic, thus achieving triple bottom line as designated by John Elkington (1994). In this context, the Global Reporting Initiative (GRI) is an independent and non-profit international organization that has pioneered sustainability reporting since 1997.

One of the main goals of GRI is to provide external information about companies for consumers and stakeholders. However, Hedberg and Malmborg (2003) that analysed corporate sustainability reporting using the CSR guidelines developed by the GRI in Swedish companies one of the conclusions is that, by looking at the guidelines and collecting the required data, the management achieves a useful overview of the companies. The GRI report provided transparency and it is a way to the company and management to be closer the society and the employees. The companies that disclosure and are rated by GRI gaining visibility and increasing credibility in terms of CSR in front of stakeholders and consumers.

The first version GRI guidelines standard was released in 2000, next versions have arisen in 2002 (G2), 2006 (G3), 2011 (G3.1) and 2013 (G4). G4 is the fourth generation of the Guidelines, was launched in 2013. With over 23,000 reports rated by GRI in 106 countries recorded in its database in 2018, sustainability reporting using the GRI Standards continues to grow.

\section{Methodology and Data}

The metodology of research consists of analysis of the regulation adopted by EU-CEE countries regarding CSR using logical and comparative analysis and dynamic GRI reports analysis by countries and activity sector.

The choice of GRI database has two essences, on the one hand is the most used worldwide by stakeholders and managers, and secondly by the researchers (Schadewitz and Niskala 2010, De Klerk and De Villiers 2012, Miralles, Miralles \& Arraiano 2017, Arraiano 2018) who followed the GRI guidelines.

Our sample comprises 275 companies considered in all sectors of activity and rated by GRI over the period 2002-2018. The period under study initiate in 2002 because before that do not have a sufficient number of companies rated by GRI.

This table shows the structure of the sample in each of the 11 CEE countries 
considered, during the period of 2002 to 2018. The number of selected companies according to the GRI criteria, as well as the percentage of GRI companies in their respective country, is also shown.

Table 1: Composition of the data sample which respect to countries

\begin{tabular}{|c|c|c|}
\hline Country & $\begin{array}{c}\text { Number of GRI reports } \\
\text { published by country }\end{array}$ & $\begin{array}{l}\text { Ratio of reports issued by country to the total } \\
\text { number of reports included in GRI database (\%) }\end{array}$ \\
\hline Bulgaria & 10 & 3.65 \\
\hline Croatia & 16 & 5.85 \\
\hline Czech Republic & 18 & 6.56 \\
\hline Estonia & 7 & 2.56 \\
\hline Hungary & 68 & 24.45 \\
\hline Latvia & 9 & 3.28 \\
\hline Lithuania & 4 & 1.45 \\
\hline Poland & 102 & 37.23 \\
\hline Romania & 26 & 9.49 \\
\hline Slovak Republic & 5 & 1,83 \\
\hline Slovenia & 10 & 3.65 \\
\hline Total & 275 & 100.00 \\
\hline
\end{tabular}

Source: Own elaboration based on http:/ / database.globalreporting.org (Accessed May 2019).

As we can see in Table 1, which presents the composition data sample in respect to countries, Poland, and Hungary are the major CEE countries and are distinguished from other countries, with 102, and 68 companies in their respective countries. Poland being the leader in terms of CSR disclosure which represent the $37.23 \%$ of the country that publish sustainability reports following the GRI guidelines, followed by Hungary with 68 (which represent the $24.45 \%$ ).

The remaining countries have a number of companies very low, and are still in a very early stage in relation to GRI criteria.

First, we conducted an analysis by country and in a second stage by sector. This approach makes sense, given that among the CEE countries examined the behaviour is different, taking into account the social responsibility and sustainability did not have the same relevance in all of them. On the other hand, the sectoral level and considering all the sectors of activity there are also differences between countries.

\section{Results}

\subsection{The implementation mode of Directive 2014/95/EU in national regulation}

To identify the stage of CSR on EU-CEE countries, in table 2 the implementation mode of Directive 2014/95/EU in national regulation is presented.

Table 2 shows that most countries have opted for the transpose of Directive in Accounting law, only three countries have approved a separate law. Most countries have imposed a limit of a Net turnover or Balance sheet total, only two countries have not imposed the limit, relying solely on number of employee. Regarding the PIE most countries include more entities in this group, only in three countries are included only listed companies, credit institutions and insurance undertakings. 
The disclosure format of the reporting has been adapted in most countries, with exception of two countries. The requirement regarding auditor's involvement are the same as in the Directive for most of countries, only in three countries requirements have been adapted.

Table 2: The implementation of Directive 2014/95/EU in EU-CEE countries

\begin{tabular}{|c|c|c|c|}
\hline Indicators & Version 1 & Version 2 & Version 3 \\
\hline $\begin{array}{c}\text { Implementation of } \\
\text { Directive in law }\end{array}$ & Accounting law & Separate law & \\
\hline Countries & $\begin{array}{c}\text { Bulgaria, Croatia, Czech, } \\
\text { Bulgaria, Czech Republic, } \\
\text { Hungary, Poland, } \\
\text { Romania, Slovakia }\end{array}$ & Latvia, Lithuania, Slovenia & \\
\hline $\begin{array}{c}\text { Net turnover or } \\
\text { Balance sheet total }\end{array}$ & $\begin{array}{l}\text { over EUR } 40 \text { million or } \\
\text { over EUR } 20 \text { million }\end{array}$ & $\begin{array}{c}\text { Limits in national } \\
\text { currency (equivalent EUR) }\end{array}$ & No limits \\
\hline Countries & $\begin{array}{l}\text { Latvia, Lithuania, } \\
\text { Slovakia, Slovenia }\end{array}$ & $\begin{array}{c}\text { Bulgaria, Croatia, } \\
\text { Czech Republic, Hungary, } \\
\text { Poland }\end{array}$ & $\begin{array}{l}\text { Estonia, } \\
\text { Romania }\end{array}$ \\
\hline $\begin{array}{l}\text { Public Interest } \\
\text { Entities (PIE) }\end{array}$ & $\begin{array}{c}\text { Listed companies } \\
\text { Credit institutions } \\
\text { Insurance undertakings }\end{array}$ & $\begin{array}{c}\text { PIE from version } 1 \text { and } \\
\text { other entities }\end{array}$ & \\
\hline Countries & Estonia, Latvia, Slovenia & $\begin{array}{c}\text { Bulgaria, Croatia, Czech } \\
\text { Republic, Poland, Romania, } \\
\text { Lithuania, Slovakia }\end{array}$ & \\
\hline $\begin{array}{c}\text { Disclosure } \\
\text { Format }\end{array}$ & $\begin{array}{l}\text { Requirements were the } \\
\text { same as in the Directive }\end{array}$ & $\begin{array}{c}\text { Requirements have been } \\
\text { adapted }\end{array}$ & \\
\hline Countries & Poland, Romania & $\begin{array}{c}\text { Bulgaria, Croatia, Czech } \\
\text { Republic, Estonia, Hungary, } \\
\text { Latvia, Lithuania, Slovakia, } \\
\text { Slovenia }\end{array}$ & \\
\hline $\begin{array}{l}\text { Auditor's } \\
\text { involvement }\end{array}$ & $\begin{array}{c}\text { Requirements are the } \\
\text { same as in the Directive }\end{array}$ & $\begin{array}{c}\text { Requirements have been } \\
\text { adapted }\end{array}$ & \\
\hline Countries & $\begin{array}{l}\text { Croatia, Czech Republic, } \\
\text { Estonia, Hungary, } \\
\text { Lithuania, Poland, } \\
\text { Slovakia, Slovenia }\end{array}$ & $\begin{array}{l}\text { Bulgaria, } \\
\text { Latvia, } \\
\text { Romania }\end{array}$ & \\
\hline Report type & Management report & Separate report & Annual report \\
\hline & OR & OR & \\
\hline Countries & $\begin{array}{l}\text { Bulgaria, Estonia, Latvra, } \\
\text { Poland, Romania, Slovenia }\end{array}$ & $\begin{array}{l}\text { Bulgaria, Croatia, Czecn } \\
\text { Rep., Latvia, Lithuania, } \\
\text { Poland, Romania, Slovenia }\end{array}$ & $\begin{array}{l}\text { Croatia, Czech } \\
\text { Rep., Hungary, } \\
\text { Lithuania, Slovakia }\end{array}$ \\
\hline
\end{tabular}

Source: own representation based on the article "Member State Implementation of Directive 2014/95/EU”, published by CSR Europe and GRI in 2017

The report type in which the information is presented can be management report, separate report published with management report or annual report. It is noted that most countries consider the option to report information in a separate report without being mandatory. Hungary and Slovakia mentioned that the information should only be published in the annual report and Estonia has opted only for the report management. Other countries allow companies to choose between two or three different report type.

\subsection{GRI evolution analysis}

\subsubsection{GRI by country}

In Figure 1 we can see that in 2002 the disclosure of corporate social responsibility was at the beginning. The first sustainability reports which was elaborated 
in CEE countries and classifieds under GRI guidelines have arose in 2002 with just three companies installed in Hungary in different sectors of activity, Denso Manufacturing Hungary (automotive), Budapest Power Plant in Hungary (energy utilities), British American Tobacco Hungary (tobacco). In this year the CSR in this part of Europe initiated the way of CSR that was yet in embryonic stage.

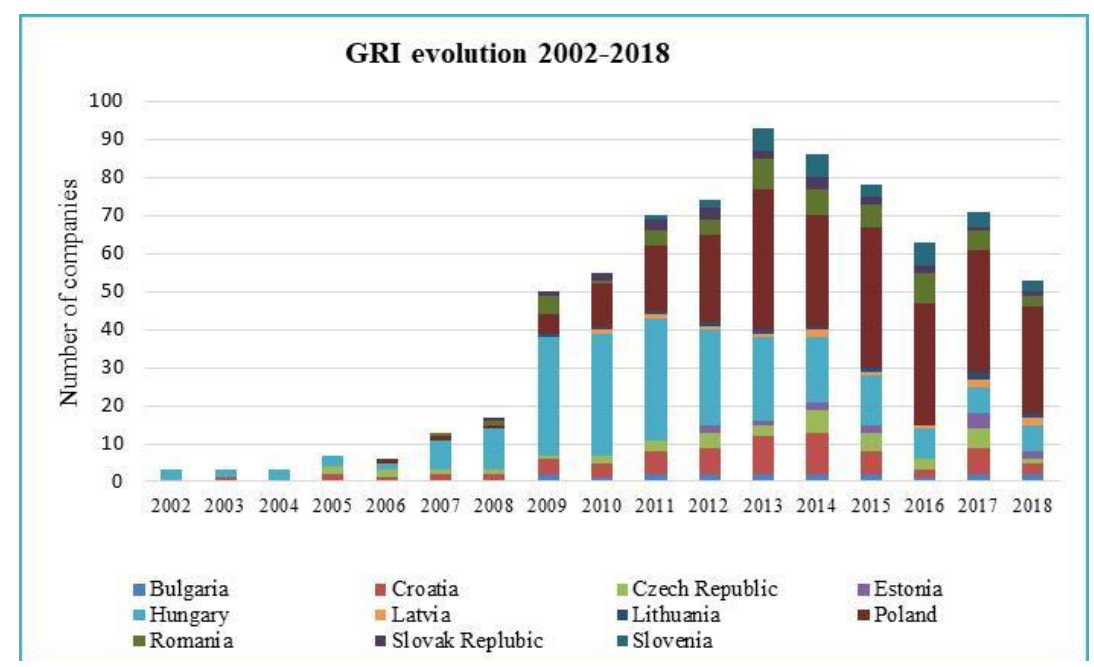

Figure 1. Evolution of GRI in CEE countries

Source: Own elaboration based on http:/ / database.globalreporting.org (Accessed May 2019).

Among the 275 companies that comprise our database, we verified that 188 companies are classified as large companies, 50 are multinational enterprises (MNE) and 37 are classified as small and medium size companies (SMEs).

In terms of company size, Gjolberg (2009) concluded that countries with fewer but larger companies have an advantage since they have more companies with the resources to participate in international CSR initiatives.

In 2009 we saw a sharp increase in the number of companies rated by GRI, but there is a decrease between 2013 and 2016. Regarding the GRI Reports, the decrease of number of reports may be caused by the application of the Directive, because the information about sustainability was included in management reports or separated report, and maybe some companies have not published the report according to GRI standards.

According Letica (2008), CEE countries can be grouped in three subgroups: the New Central European, The Baltic and the Western Balkan. The New Central Europe are formed by Czech Republic, Slovakia, Poland, Hungary, Slovenia and Croatia. The Baltic, including Estonia, Latvia and Lithuania. Western Balkan, includes Bulgaria and Romania (Fig 2).

The CEE countries do not enter in EU at the same time. Czech Republic, Estonia, Hungary, Latvia, Lithuania, Poland, Slovak and Slovenia are a member country of the EU since May 1, 2004, Bulgaria and Romania since January 1, 2007 and the last one was Croatia in July 1, 2013.

In Poland, from 2009 we witnessed a quantitative increase in the number of companies 
through the GRI standard. The peak occurs in the years 2013 and 2015, with 37 companies, while in the following years we have seen a slight decrease and in 2018 this number is just 28 companies.

Poland is the country with the highest number of companies that comply with the requirements of social responsibility and sustainability, respecting its three fundamental pillars, economic, social and environmental in its management strategy.

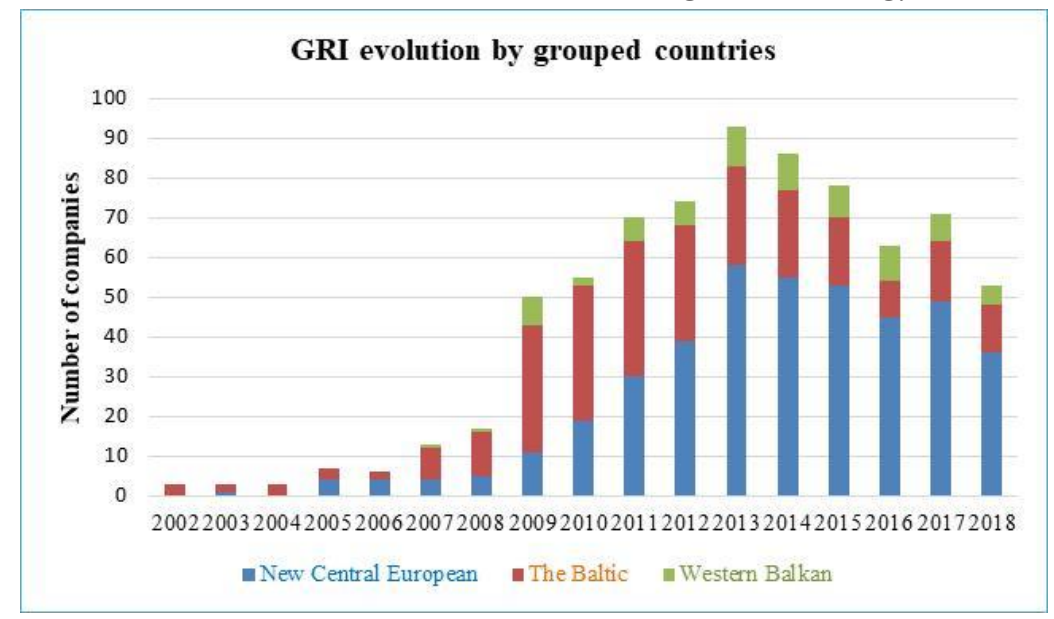

Figure 2. GRI evolution by grouped countries

Source: Own elaboration based on http:/ / database.globalreporting.org (Accessed May 2019).

Figure 3 shows the evolution of the number of companies that were classified by the GRI under the study period. We can observe the differences between the number of companies in each of the eleven countries. In this analysis Hungary and Poland are distinguished from the others, followed by Croatia and Romania, Slovenia and the Czech Republic. While Bulgaria, Estonia, Latvia, Lithuania and Slovak Republic are the countries in which a minority of companies are perceived that present strategies of social responsibility and sustainability according to GRI guidelines.

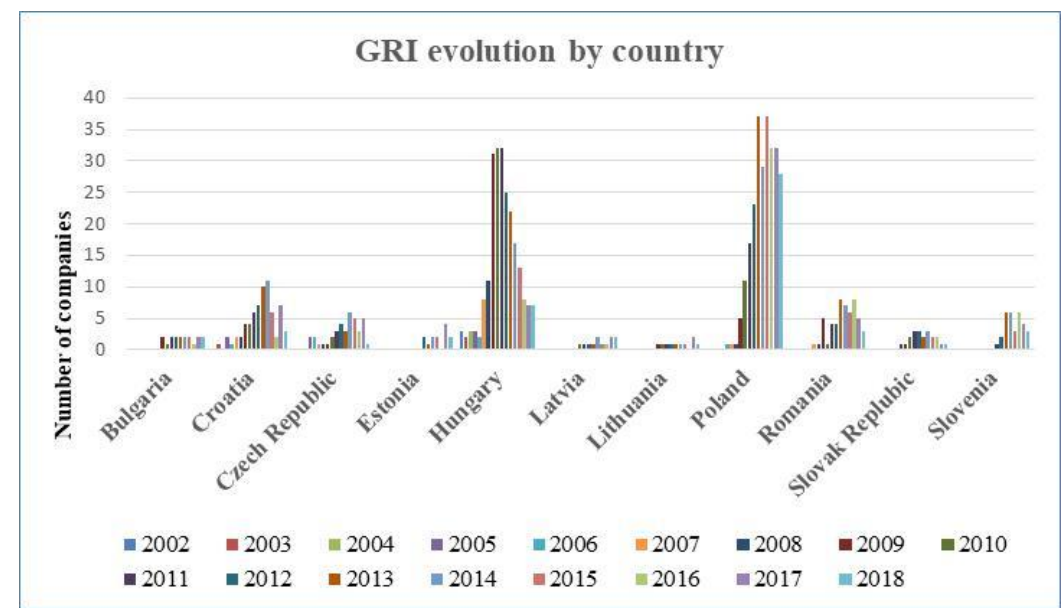

Figure 3. Evolution of the number of companies rated by GRI from 2002 to 2018

Source: Own elaboration based on http:/ / database.globalreporting.org (Accessed May 2019). 


\subsubsection{GRI by Sector}

Most of GRI reports are presented by large multinational corporations, in such sectors as financial services namely in banking, telecommunications, energy, food and beverage and healthcare products.

Figure 4 illustrates well the sectors that have most contributed to the list of companies classified by the GRI over the study period. We can see that the financial sector plays a very important role in society since all the sectors of activity it uses to finance its business. Most of these financial institutions are the largest banks in Poland, and the largest listed banks in Warsaw Stock Exchange which is the largest stock exchange in Eastern Europe and one of the most recognized Polish financial institutions.

Fijałkowska et al. (2017) empirically analyzed the impact of all public companies in the financial sector in Poland over 2012-2015 period being socially responsible and what are the financial consequences CEE region.

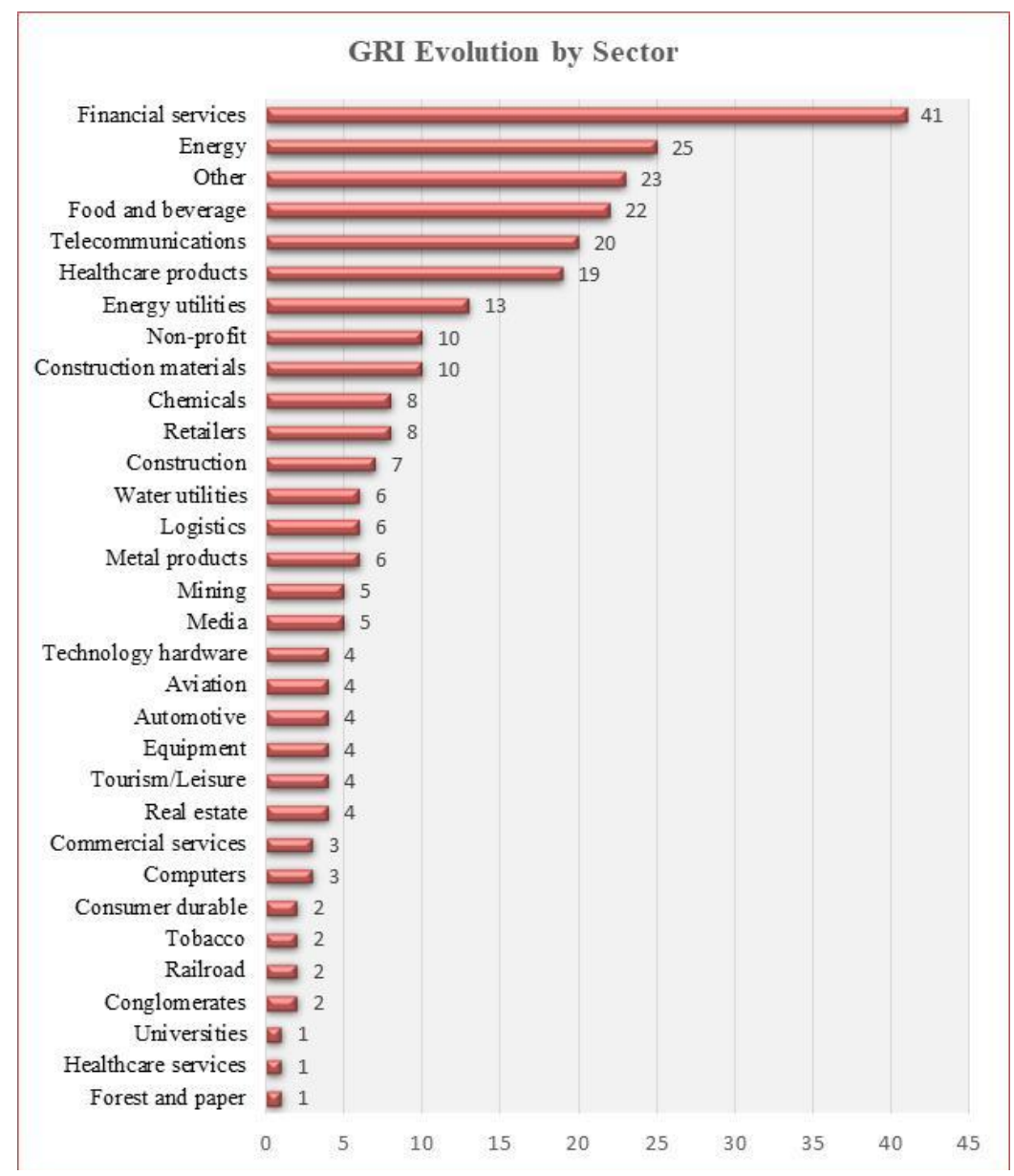

Figure 4. Evolution of the number of companies rated by GRI from 2002 to 2018

Source: Own elaboration based on http:/ / database.globalreporting.org/ search (Accessed May 2019). 
After the financial crisis of 2008, banks have realized the importance of being socially responsible, and prepare sustainability reports would be a way to regain credibility and gain the trust of investors and customers in general (Cornett et al., 2014).

The results of our research are based on literature review, the analysis of GRI reports found that there was a gap to the Western Europe countries, but the application of the Directive's requirements could reduce this gap and and can improve the quality of reporting. Most reports were published by companies in Poland, the country with the largest number of enterprises.

\section{Conclusion}

The corporate social responsibility disclosure has grown substantially worldwide and especially in Europe in the last decades. We find that the various regions of Europe have substantial differences in their behaviour regarding the practice of preparing and submitting non-financial reports, which is due to different government policies and cultures. Throughout the study period, we have seen their integration into the EU, resulting in an increase in the number of companies that follow the GRI guidelines. In this context, and under the influence of the economic policies defined by the European Commission over these years, as well as the policies and legislation of each European country, many companies consider it advantageous to publish sustainability reports, thus providing that information to their stakeholders and consumers.

This study shows that the stage of Corporate Social Responsibility in EU-EEC countries is still in a very embryonic state. Poland and Hungary stand out as leading countries in social responsibility and sustainability strategies. While the managers of companies based in the other countries of this region have not yet understood the advantages of adopting this strategy in their management.

Nevertheless, this study shows that the majority of firms still not disclose according GRI guidelines. There is a significant difference between EU-CEE countries and developed European countries (Arraiano, 2018). As we expected, the results show that the evolution of reporting practices has improved over the years in each other eleven countries of this European region and the most reports are prepared by multinationals companies.

One limitation of the study is to consider only a database in which most are large companies. Even though GRI criteria are the standards most widely used by companies to provide high-quality CSR information there are other databases that can be considered and that broaden our spectrum of analysis, thus covering more companies. Future research will consist of conducting empirical studies on the influence of CSR reports on the performance of companies in EU-CEE countries.

\section{Acknowledgements}

Irene Arraiano thanks to Lisbon Polytechnic Institute that has been funded this research which is part of the Project ASIAN13, under the Research, Development, Innovation and Artistic Creation Project (IDI\&CA)-2019 referenced by IPL/2019/ASIAN13/ISCAL).

Camelia Daniela Hategan's work was supported by a mobility grant of the 
Romanian Ministry of Research and Innovation, CNCS - UEFISCDI, project number PN-III-P1-1.1-MC-2019-0576, within PNCDI III.

\section{References}

Arraiano, I.G. (2018). The impact of Socially Responsible Investing in European Markets: Evidence of the Global Financial Crisis, European Journal of Sustainable Development, 7 (4), 95-104.

Borbély, C., Szabó-Szentgróti, G., Szabó-Szentgróti, E., Csonka, A., \& Kőműves, Z. (2014). CSR analysis of large Hungarian enterprises. Regional and Business Studies, 6(2), 1-7. Retrieved from http://journal.ke.hu/index.php/rbs/article/view/574

Cornett, M. Erhemjamts, O. \& Tehranian, H. (2014) Corporate social responsibility and the impact on financial performance: Investigation of U.S. commercial banks, Boston college, from https://www2.bc.edu/hassantehranian/CSR-

Performance\%20Relationship\%20for\%20Banks\%20Jan\% 202014.pdf

CSR Europe and GRI (2017). Member State Implementation of EU Directive (Directive 2014/95/EU), pp 16-31, Available https://www.globalreporting.org/resourcelibrary/nfrpublication\%20online_version.pdf

Dagiliene, L., Leitoniene, S. \& Grencikova, A. (2014). Increasing Business Transparency by Corporate Social Reporting: Development and Problems in Lithuania Inzinerine Ekonomika-Engineering Economics, 25(1), 54-61

De Klerk M, De Villiers C. (2012). The value relevance of corporate responsibility reporting: South African evidence. Meditari Accountancy Research 20 (1): 21-38

Dumitru, M.; Dyduch, J.; Guse, R. \& Krasodomska, J. (2016) Corporate reporting practices in Poland and Romania-An ex-ante study of the non-financial reporting European Directive. Accounting in Europe 14, 29-304

Dura, C., \& Drigă, I. (2017). The impact of multinational companies from Romania on increasing the level of corporate social responsibility awareness. Contemporary Economics, 11(1), 45-66.

Elkington, J. (2010). Cannibals with Forks, The Triple Bottom Line of $21^{\text {st }}$ Century Business, Majeure Alternative Management, HEC, Paris

European Commission. 2001. Green Paper. Promoting a European framework for corporate social responsibility. www.i-csr.org/repository/ECcom2001_0366en01.pdf

Fijałkowska, J., Zyznarska-Dworczak, B. and Garsztka, P. (2017). The relation between the CSR and the accounting information system data in Central and Eastern European (CEE) countries - the evidence of the Polish financial institutions, Accounting and Management Information Systems, 16 (4), 490-521

Golob, U. \& Podnar, K. (2014). Slovenia: CSR as a luxury in tough economic times. In Preuss, L., Gold, M. and Rees, C. (eds.) Routledge.Corporate Social Responsibility and Trade Unions, Across Europe, Chapter 9, 161-176, London: Routledge.

Gjolberg, M. (2009), Measuring the immeasurable? Constructing an index of CSR practices and CSR performance in 20 countries, Scandinavian Journal of Management 25, 10-22.

Habek, P. (2017) CSR Reporting Practices in Visegrad Group Countries and the Quality of Disclosure.Sustainability, 9, 2322.

Hedberg, C. J. \& Von Malmborg, F. (2003). The global reporting initiative and corporate sustainability reporting in Swedish companies, Corporate social responsibility and environmental management, 10(3), 153-164.

Horváth, P., Pütter, J. M., Dagilienė, L., Dimante, D., Haldma, T., Kochalski, C.,. \& Pakšiová, R. (2017.a). Status quo and future development of sustainability reporting in Central and Eastern Europe. JEEMS Journal of East European Management Studies, 22(2), 221-243

Horváth, P., Pütter, J. M., Haldma, T., Lääts, K., Dimante, D., Dagilienė, L., \& Pakš̌ová, R. (2017.b). Sustainability reporting in Central and Eastern European companies: Results of an international and empirical study. In Sustainability Reporting in Central and Eastern European Companies (pp. 11-49). Springer, Cham.

Hys, K. \& Hawrysz, L. (2012), Corporate Social Responsibility Reporting, China-USA Business Review, ISSN 1537-1514, 11 (11), 1515-1524.

Kooskora, M. (2015). Corporate Social Responsibility in Estonia: Moving Towards a More Strategic Approach. In: S. Idowu, R. Schmidpeter and M. Fifka, ed., Corporate Social Responsibility in Europe. United in Sustainable Diversity, 1st ed. Springer, pp. 291-312. 
Kukanja, M., Planinc, T. \& Šuligoj, M. (2016). Influence of managers' demographic characteristics on CSR practices in the restaurant industry: the case of Slovenia. Tourism and bospitality management, 22(2), 151-172.

Leitoniene, S. \& Sapkauskiene, A. (2015) Quality of Corporate Social Responsibility Information. Procedia Soc. Behav. Sci., 213, 334-339.

Letica, B. (2008). Three CSR Models in New European Union Member States and Candidate Countries, Fondarione ENI Enrico Mattei, CSR paper 43.

Maj, J. (2018). Environmental Reporting in Polish Organisations Environmental Economics Maj 18th International Multidisciplinary Scientific GeoConference SGEM 2018, 351-358

Matuszak, L. \& Rózanska, E. (2017). CSR Disclosure in Polish-Listed Companies in the Light of Directive 2014/95/EU Requirements: Empirical Evidence. Sustainability, 9, 2304

Miralles-Quirós, M., Miralles-Quirós, J. \& Arraiano, I. (2017) Are Firms that Contribute to Sustainable Development Valued by Investors? Corporate Social Responsibility and Environmental Management, 24 (1), 71-84.

Ogrean, C. (2017). The Directive 2014/95/EU-Is there a "New" Beginning for CSR in Romania? Studies in Business and Economics, 12(1), 141-147.

Pakšiová, R. (2016). CSR Reporting in Slovakia. Proceedings of the 3rd International Conference on European Integration 2016 (ICEI 2016), 698-707

Pataki, G., Szántó, R., \& Matolay, R. (2015). CSR online and in real terms: A critical analysis of controversial sectors in Hungary. In Corporate social responsibility in the digital age (pp. 241-264). Emerald Group Publishing Limited.

Peršić, M. \& Halmi, L. (2018). Exploring the quality of social information disclosed in non-financial reports of Croatian companies, Economic Research - Ekonomska Istraživanja, 31(1), 2024-2043

Petera, P., Wagner, J., \& Knorová, K. (2016). Perception and interpretation of sustainability among the largest corporations established in the Czech Republic. Acta Universitatis Agriculturae et Silviculturae Mendelianae Brunensis, 64(3), 1053-1065.

Rajnoha, R., Lesníková, P. \& Korauš, A. (2016). From Financial Measures to Strategic Performance Measurement System and Corporate Sustainability: Empirical Evidence from Slovakia, Economics and Sociology, Vol. 9, No 4, pp. 134-152.

Schadewitz H, Niskala M. 2010. Communication via responsibility reporting and its effect on firm value in. Finland Corporate Social Responsibility and Environmental Management 17(2): 96-106.

Scholtens, B. \& Dam, L. (2007). Cultural Values and International Differences in Business Ethics, Journal of Business Ethics, 75 (3), 273-284.

Simeonov, S. \& Stefanova, M. (2015). Corporate Social Responsibility in Bulgaria: The Current State of the Field. In: S. Idowu, R. Schmidpeter and M. Fifka, ed., Corporate Social Responsibility in Europe. United in Sustainable Diversity, 1st ed. Springer, pp.313-332.

Simionescu, L. \& Dumitrescu, D. (2018). Empirical Study towards Corporate Social Responsibility Practices and Company Financial Performance. Evidence for Companies Listed on the Bucharest Stock Exchange. Sustainability 10(9), 3141.

Skýpalová, R., Kučerová, R. \& Blašková, V. (2016). Development of the Corporate Social Responsibility Concept in Small and Medium-Sized Enterprises, Prague Economic Papers, University of Economics, Prague, vol. 2016 (3), pages 287-303.

Steurer, R., \& Konrad, A. (2009). Business-society relations in Central-Eastern and Western Europe: How those who lead in sustainability reporting bridge the gap in corporate (social) responsibility. Scandinavian Journal of Management, 25(1), 23-36.

Steurer, R., Martinuzzi, A., \& Margula, S. (2012). Public policies on CSR in Europe: Themes, instruments, and regional differences. Corporate Social Responsibility and Environmental Management, 19(4), 206-227.

Strouhal, J.; Gurvits, N.; Nikitina-Kalamäe, M.; \& Startseva, E. (2015). Finding the link between CSR reporting and corporate financial performance: Evidence on Czech and Estonian listed companies. Cent. Eur. Bus. Rev. 4, 48-59.

Tambovceva, T., Titko, J. \& Alksne, A. (2017). Corporate Social Responsibility Perceived by Latvian Enterprises. Conference: 30th International Business-Information-Management-Association Conference Madrid, Spain Nov 08-09, Sustainable Economic Development, Innovation Management and Global Growth, Vol I-IX, 1557-1568. 